\title{
Development of Problem-Based Kinematics Teaching Material to Improve Students' Critical Thinking Skills
}

\author{
Inung Diah Kurniawati \\ Informatics Engineering, University of PGRI Madiun \\ inungdiah@unipma.ac.id
}

Received: February $13^{\text {th }}, 2016$. Revised: February $26^{\text {th }}, 2019$. Accepted: February $27^{\text {th }}, 2019$

\section{Keywords :}

Teaching Material;

Problem-Based; Critical

Thinking

\begin{abstract}
Physics learning needs to be given by giving problems so that students can gain experience from their thinking abilities. Student's mindset will be more focused if they are able to think critically. The purpose of this study was to develop problem-based teaching material to improve informatics engineering students' critical thinking skills. With this teaching material development, students are expected to be able to maximize their thinking skills. This study used development research design that aimed to produce a problem-based physics teaching material. The trial subjects for this teaching materials were 3 lecturers and 12 informatics engineering students from University of PGRI Madiun. From this study, quantitative and qualitative data were obtained. The obtained data from the assessment of lecturers and students will be analyzed by average analysis technique. From the average value obtained, the feasibility level of problem-based teaching material will be determined. Based on the results of the analysis, the average value of 3.33 with good category were obtained. Furthermore, the results of this teaching materials development can be used in the implementation test. Teaching materials were needed by students to gain direct experience in learning physics.
\end{abstract}

\section{INTRODUCTION}

The physics course is a compulsory subject in the informatics engineering study program. Physics courses learn about natural symptoms that occur in this world. The subject of physics consists of measurements, vectors, kinematics, dynamics, work and energy, momentum impulses, dynamics of rotational motion, heat, and waves. The emphasis in this study was developing kinematics teaching materials, because kinematis is the foundation for the next subjects. Kinematics learns about motion without seeing the cause. 
Nowadays college graduates need to be equipped with critical thinking skills. This ability is needed to enter community life and work. Therefore, physics learning needs to be given by giving problems so that students' critical thinking skills increase. The students' mindset will be more focused if they are accustomed to think critically.

Physics is the science that learns about nature with various forms of symptoms that occur. The concept of natural phenomena is obtained by scientists through a long process, so that concepts, laws, postulates and so on are obtained. In accordance with temperature physicists, physics learning is inseparable from understanding physics concepts, one of which is through the process of understanding and thinking. Understanding the concept will be solved if the learning begins with problems. Therefore, a thinking process is needed in learning physics.

Thinking is a natural process carried out by each individual in solving problems in daily life. Thinking ability consists of basic thinking and high-level thinking [1]. Furthermore, high-level thinking itself is divided into four groups, namely problem solving, making decisions, critical thinking and creative thinking [2]. The indicators in this study use critical thinking skills.

The ability to think critically needs to be instilled in students through the use of thinking at a higher level at each level, so that their thinking skills will be honed. Naturally, students will build reasonable thoughts. Critical thinking is the ability to analyze and evaluate data or information [3]. Furthermore, Ennis stated that critical thinking is a rational and reflective thinking concept that focuses on deciding what to do [4]. Based on these explanations, it can be concluded that critical thinking is a decisionmaking process in solving problems with the process of analyzing and interpreting data. Indicators of critical thinking skills consist of, (1) defining and classifying problems, (2) assessing information that is linked to problems, and (3) solving problems or drawing conclusions [5]. Furthermore, Ennis explained the indicators of critical thinking ability which consisted of 12 indicators [4].

Based on the description above, it is necessary to design a teaching material that is able to improve students' critical thinking skills in the learning process, one of which is by giving problems. From the development of this teaching material, students are expected to master the basic concepts of physics better, through a thought process. The purpose of this study is to develop problem-based teaching materials in improving the informatics engineering students' critical thinking skills.

Some previous studies show that the development of teaching materials can improve thinking skills. The research conducted by Sudaryati et al. Showed that the development of problem-based modules to improve students' creative thinking skills was feasible [6]. In addition, research conducted by Maulida and Simanjuntak showed the feasibility of student-based teaching materials in improving student learning outcomes. This proves that teaching materials in learning need to be developed to achieve expectations [7]. Student's achievement in physics can be improved by using the problem based [8].

\section{METHOD}

This study uses a development research design. From this development research, it is expected to produce a product in the form of problem-based physics teaching materials on kinematics material. According to Borg and Gall, development research consists of ten steps which are the development cycle to produce a product [9]. In this study, the researcher adjusted the ten main steps to the conditions of the research to be carried out. Therefore, this problem-based teaching material was developed with the first five steps in development research. Five steps of development are carried out, namely (1) preliminary study, (2) planning, (3) product development, (4) initial field test, and (5) main product revisions.

The testing step used is the feasibility test of teaching materials with certain criteria. Criteria feasibility test is a validation that involves a level problem, where the scale used is able to predict a variable designed as a criterion [10]. 
Feasibility test data is obtained from assessments, responses, criticisms and suggestions from experts and students. The assessment results obtained are in the form of feasibility tests that are used to assess the feasibility of teaching materials that have been developed. Whereas responses, criticisms and suggestions are used to make revisions to improve the product being developed.

The subjects of the trial were three expert lecturers at the University of PGRI Madiun and 12 informatics engineering students from 4 different classes who had different abilities. This was done to determine the level of readability of the developed teaching materials. In this study qualitative data and quantitative data were obtained. Quantitative data includes the average value of expert and user (student) validation questionnaires. The quantitative data is then carried out an average analysis to draw conclusions about the feasibility of teaching materials. While qualitative data in the form of responses, criticisms, and suggestions from lecturers and students are used to evaluate the developed learning materials.

The obtained data from assessments by lecturers and students were analyzed by average analysis techniques. The average score that has been obtained then used to determine the feasibility level of problem-based teaching materials. The average score analysis technique used in the study to state that in knowing the final grade rating for each assessment questionnaire, the number of values can be obtained by dividing the number of respondents who answered the questionnaire [11]. Then the following average value formula is obtained.

$$
\bar{X}=\frac{\sum x}{n}
$$

Where: $\begin{aligned} \bar{X} & =\text { Average score } \\ \Sigma \mathrm{x} & =\text { Total score assessment answers } \\ \mathrm{n} & =\text { Number of assessors }\end{aligned}$

The rating scale in this study is 1 as the lowest value and the highest value is 4 . Table 1 shows the eligibility criteria for the average analysis results.

Table 1. Average Results Eligibility Criteria

\begin{tabular}{ccc}
\hline No & Average score & Category \\
\hline 1 & $3.26-4.00$ & Feasible \\
2 & $2.51-3.25$ & Quite feasible \\
3 & $1.76-2.50$ & Less feasible \\
4 & $1.00-1.75$ & Not feasible \\
\hline
\end{tabular}

\section{RESULTS AND DISCUSSIONS}

\section{Preliminary studies}

The preliminary study phase is a step to identify problems in the learning process of physics courses. This is used as the basis for designing teaching material products to be developed. Based on the final semester exam, student scores on kinematics are still low which is an average of 68 . In addition, questionnaires are also distributed to students of informatics engineering who have taken physics courses and interviewed the students. The results show that a teaching material is needed to facilitate students in learning physics. During this time, in learning physics using literature books and e-books. The problems in the books do not motivate students to study physics. Based on the results of observations, it can be concluded that the problem-based learning method has not been maximally applied. This clearly shows that student thinking activities are not optimal as well. Therefore, problembased teaching materials are needed to improve students' thinking skills, especially critical thinking. 


\section{Planning}

The planning stage aims to make the initial design of problem-based physics teaching materials. The flow of this stage is to determine: a) the expected learning outcomes and final abilities in kinematics material; b) the relationship between problem-based teaching materials and critical thinking; c) designing teaching materials and d) designing questions about the ability to think critically in accordance with the indicators.

\section{Product Development}

At this stage the design of instructional materials developed was produced. Teaching materials consist of 3 main parts, namely introduction, contents, and closing. Teaching materials developed by researchers include cover pages, inner cover pages, introductory pages, instructions for using problem-based teaching materials, table of contents, expected goals, contents, concluding, and research instruments.

\section{Initial Field Test}

The initial product field test is part of the validation stage. Validation is done by experts and limited trials are applied to students. Expert validation is carried out by experts and practitioners. Meanwhile, limited trials were conducted on 12 Informatics Engineering students who had taken physics courses. Students read and understand all the parts in the teaching material and then fill out the readability questionnaire of teaching materials. In Table 2 is the result of field test validation. And the readability test of teaching materials by students can be seen in Table 3 .

Table 2. Expert Validation Results

\begin{tabular}{cccc}
\hline No & Validation & Average & Category \\
\hline 1 & Depth of Material & 3.40 & Feasible \\
2 & Layout & 3.26 & Feasible \\
3 & Use of Language & 3.33 & Feasible \\
\hline
\end{tabular}

Table 3. Limited Field Test Results

\begin{tabular}{clcc}
\hline No & \multicolumn{1}{c}{ Aspect } & Average & Category \\
\hline 1 & Effectiveness of sentences & 3.32 & Feasible \\
2 & Word difficulty level & 3.39 & Feasible \\
3 & Content & 3.32 & Feasible \\
\hline
\end{tabular}

\section{Main Product Revisions}

The main product revision is carried out to improve teaching materials before the implementation test. Based on the results of validation, solutions were obtained for the development of teaching material products. The results is, the revision of the phenomenon given to straight motion where initially the vehicle motion event should be replaced with more challenging phenomenon, namely comparing the motion of the vehicle with the motion of fruit falling from the tree. In addition, the material presented in teaching materials needs to be more clarified. Furthermore, the results of the revision regarding the arrangement of teaching materials are less proportional to the image aspect. The results of the analysis of the validation carried out by students obtained a study in several parts of teaching materials that must be revised. Some things that need to be revised in learning activities are: 1) improving the table of observations; 2) instructions in processing data and charting; and 3) add questions about the graph. The teaching materials that have been developed and revised are presented in Fig 1, 2, and 3 as follows.

Teaching materials are needed by students to gain direct experience in learning physics. In addition, teaching materials can improve students' thinking skills. The results obtained from this development are teaching materials to improve students' critical thinking skills. Overall, the results of the teaching material validation obtained an average value of 3.33 which is categorized as feasible. Problem-based teaching material is feasible to enhance student creative thinking [12]. In addition, problem-based physics teaching materials are oriented to the ability to solve physics problems and physics learning 
achievements are feasible [13]. In addition, Anisah and Lastuti state that the development of hot-based teaching materials to improve students' problem solving skills is feasible [14].
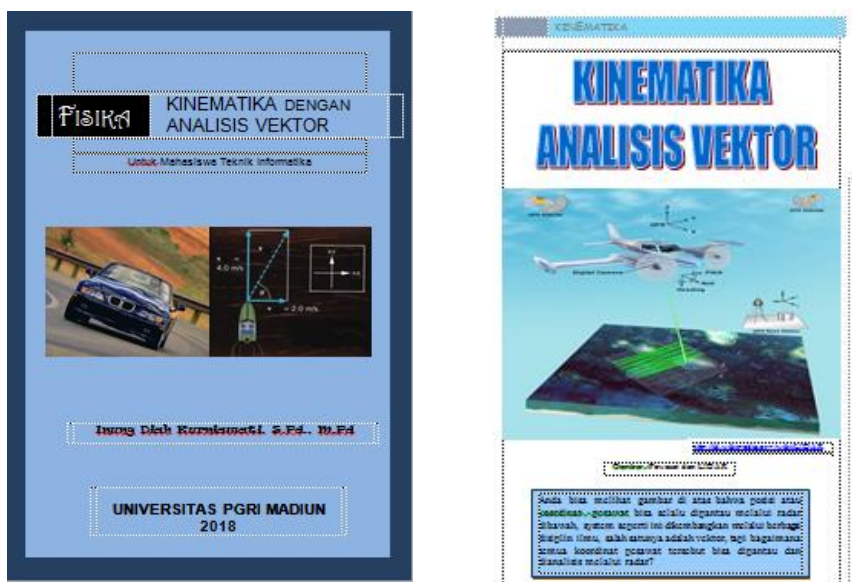

Fig 1. Cover page and homepage
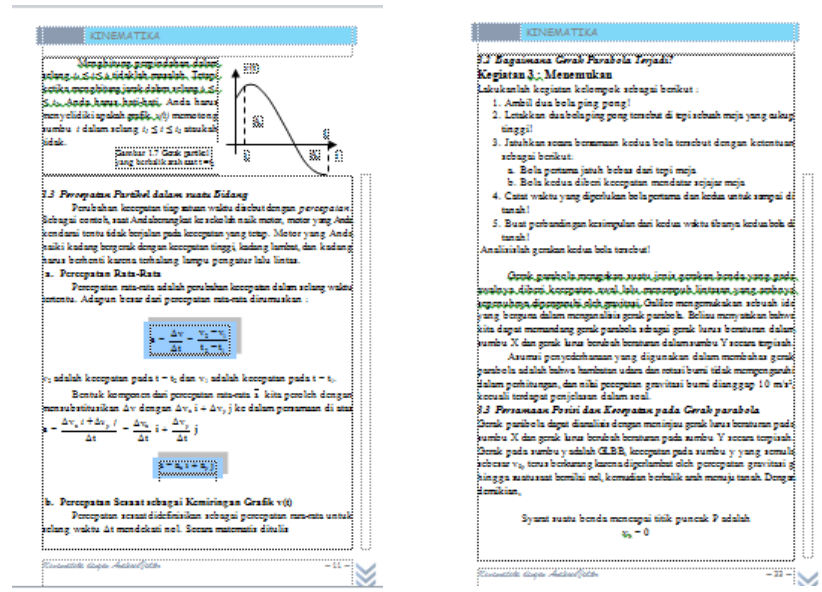

Fig 2. Content page and activity page
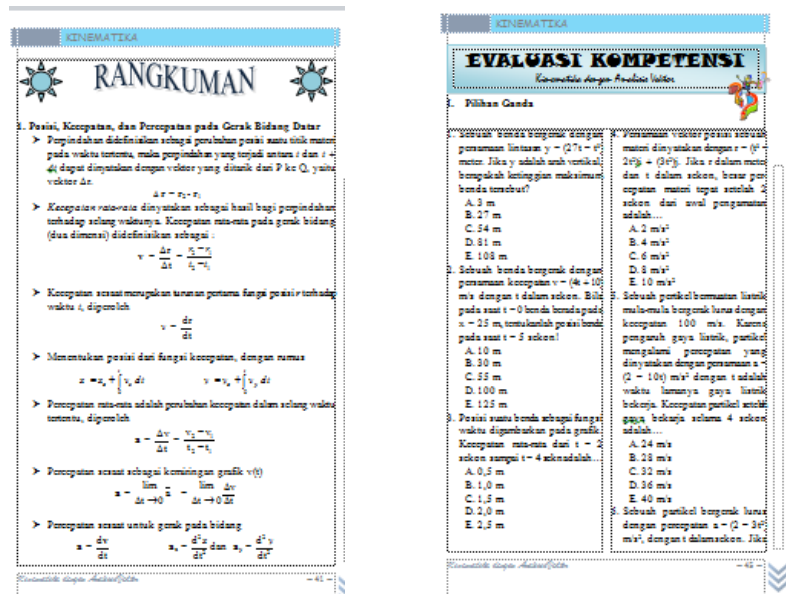

Fig 3. Summary page and question evaluation page

Critical thinking skills are needed by every student. Paul states that critical thinking is built on skills, such as finding conclusions, examining places, forming conclusions and diagnosing errors [15] [16]. Giving problems in learning is one way to develop critical thinking skills. This is in line with the research of Shaer and Gaber, which shows that there is a significant increase in critical thinking skills between 
problem-based learning and conventional learning [17]. Problem-based teaching material is one way to be applied in learning to improve critical thinking skills.

\section{CONCLUSION AND SUGGESTION}

\section{Conclusion}

This development of problem-based physics teaching materials in kinematics material is to improve students' critical thinking skills. The results of the validation of physics teaching materials are stated to be feasible to use as teaching material for the course. The feasibility of teaching materials based on the assessment gets an average score of 3.33 .

Suggestion

For further research, it is recommended to conduct further research on problem-based teaching materials by conducting empirical feasibility tests to obtain teaching materials that have been tested for their theoretical and empirical feasibility. In addition, it also needs to be developed: 1) physics-based teaching materials based on problems with other materials; and 2) physics teaching materials to improve other thinking skills. So that there is a complete textbook used in physics subjects.

\section{REFERENCES}

[1] Krulik, S., \& Rudnik, J. A. (1996). The New Source Book Teaching Reasoning and Problem Solving in Junior and Senior High School. Massachusets: Allyn \& Bacon.

[2] Costa, A. L. (1985). Developing Mind. Virginia: Association for supervision and Curiculum Development.

[3] Duron, R., Limbach, B., \& Waugh, W. (2006). Critical thinking framework for any discipline. International Journal of Teaching and Learning in Higher Education, 17(2): 160-166.

[4] Ennis, R. H. (1993). Critical thinking assessment. Theory into practice, 32(3): 179-186.

[5] Hestiningsih, N., \& Sugiharsono, S. (2015). Peningkatan Kemampuan Berpikir Kritis Peserta Didik Pembelajaran IPS melalui Metode Problem Solving Berbantuan Media Informasi Harmoni Sosial: Jurnal Pendidikan IPS, 2(1): 71-86.

[6] Sudaryanti, A., Suparmi, \& Sarwanto. (2017). Pengembangan Modul Fisika Berbasis Masalah Pada Materi Listrik Dinamis Untuk Meningkatkan Kemampuan Berpikir Kreatif Siswa Kelas X SMA/MA. Inkuiri: Jurnal Pendidikan IPA, 6(3): 127-140.

[7] Maulida, R., \& Simanjuntak, M. P. (2015). Pengembangan Bahan Ajar Fisika Sma Berbasis Investigasi Pada Materi Fluida Dinamis Untuk Meningkatkan Hasil Belajar Siswa. Jurnal Pendidikan Fisika, 4(1): 71-76.

[8] Ahlam, E. S., \& Gaber, H. (2014). Impact of problem-based learning on studentscritical thinking dispositions, knowledge acquisition and retention. Journal of Education and Practice, 5(14): 7483.

[9] Argaw, A. S., Haile, B. B., Ayalew, B. T., \& Kuma, S. G. (2017). The effect of problem based learning (PBL) instruction on students' motivation and problem solving skills of physics. EURASIA Journal of Mathematics Science and Technology Education, 13(3): 857-871.

[10] Borg, W. R., \& Gall, M. D. (1983). Educational Research: An Introduction. New York: Longman.

[11] Mufidah, I. (2008). Pengembangan Bahan Ajar IPA Terpadu Berbasis Sains-LingkunganTeknologi-Masyarakat (SALINGTEMAS) Untuk SMP Kelas VII Semester I. Skripsi. Program Studi Pendidikan Fisika. Universitas Negeri Malang.

[12] Arikunto, S. (2006). Prosedur Penelitian Suatu Pendekatan Praktik. Jakarta: Rineka Cipta.

[13] Erawanto, U. (2016). Pengembangan modul pembelajaran berbasis masalah untuk membantu meningkatkan berfikir kreatif mahasiswa. JINoP (Jurnal Inovasi Pembelajaran), 2(2): 427-436.

[14] Kharisma, J. Y., \& Asman, A. (2018). Pengembangan Bahan Ajar Matematika Berbasis Masalah Berorientasi pada Kemampuan Pemecahan Masalah Matematis dan Prestasi Belajar Matematika. Indonesian Journal of Mathematics Education, 1(1): 34-46. 
JIPF, Vol. 4 No. 1, March 2019

[15] Anisah, A., \& Lastuti, S. (2018). Pengembangan Bahan Ajar berbasis HOTS untuk Meningkatkan Kemampuan Pemecahan Masalah Matematis Mahasiswa. Kreano, Jurnal Matematika Kreatif-Inovatif, 9(2): 191-197.

[16] Fuad, N. M., Zubaidah, S., Mahanal, S., \& Suarsini, E. (2017). Improving Junior High Schools' Critical Thinking Skills Based on Test Three Different Models of Learning. International Journal of Instruction, 10(1): 101-116.

[17] Karakoc, M. (2016). The significance of critical thinking ability in terms of education. International Journal of Humanities and Social Science, 6(7): 81-84. 